\title{
Retaliation, Seriousness of Wrongdoing, and Whistleblowing: An Experimental Study in Internal Governmental Auditor
}

\author{
Gracella Theotama \\ \{gtheotama@gmail.com\} \\ Master of Accounting Department, Economics and Business Faculty, Satya Wacana Christian University, \\ Salatiga, Indonesia
}

\begin{abstract}
Whistleblowing is an anti-fraud mechanism that mitigates fraud in organizations. Studies on whistleblowing largely focus on profit-seeking firms, although fraud also exists in governmental sectors. In this respect, the role of government internal auditors is potentially important to commit whistleblowing. Several factors likely affect whistleblowing intention, including retaliation and seriousness of wrongdoing as situational factors. This study aims to test the causal relationship between retaliation and seriousness of wrongdoing on whistleblowing intention. In doing so, this paper uses a $2 \times 2$ between-subjects experimental design with 45 government internal auditors as the participants. The results show that retaliation and seriousness of wrongdoing affect whistleblowing.
\end{abstract}

Keywords: retaliation, seriousness of wrongdoing, whistleblowing

\section{Introduction}

This study is motivated by the widespread cases of corruption, collusion, and nepotism (KKN Korupsi, Kolusi, dan Nepotisme) in the Indonesian public sector. Numerous cases exist each year, and many involve accountants. A high-profile case was related to unqualified audit opinion on the 2016 financial statements of Ministry of Village, Development of Disadvantaged Regions, and Transmigration (Kemendes PDTT - Kementerian Desa, Pembangunan Daerah Tertinggal dan Transmigrasi). Corruption Eradication Commission (KPK - Komisi Pemberantasan Korupsi) named four suspects on this case, namely Sugito (the General Inspectorate of Ministry of Village), Jarot Budi Prabowo (an Echelon III Officer of Ministry of Village), Rochmadi Saptogiri (Lead Auditor III BPK or State Audit Agency) and Ali Sadli (an Echelon I Officer of BPK) (Pratiwi, 2017).

Fraud committed by individuals or groups will give significant impacts in various aspects. Dimant and Tosato (2017) explain that fraud has various negative consequences, such as suboptimal productivity levels due to inefficient fund allocation, reduced investments, economic growth slowdown, increasing income gap, and poverty rate. However, fraud can be mitigated, and fraudsters can be penalized with various methods, including whistleblowing (ACFE, 2018).

Whistleblowing is an action of members of organizations to report illegal, immoral, and illegitimate actions (Elias, 2008). Generally, whistleblower comes from internal organization however can also comes from parties outside the organization. The study of Dyck, Morse \& Zingales (2010) in 216 cases of fraud showed that $17 \%$ of these cases detected as a role of the organization's employee, $13 \%$ as a role of non-financial-market regulators, and $13 \%$ as a role of media. In Indonesia, Agus Rahardjo Head of Corruption Eradication Commission (KPK - Komisi Pemberantasan Korupsi) assert that in a sting operation (Operasi Tangkap Tangan) of fraud cases begin because of the incoming reports, then studied and carried out direct monitoring (Tallo, 2018).

Whistleblowing attracts numerous discussions because it is an effective method to combat unethical behaviors. However, it is not easy to be whistleblowers. Various factors affect individuals to commit whistleblowing. A review study of Gao and Brink (2017) maps several factors that affect individuals' intention to commit whistleblowing, namely whistleblowers' characteristics, the characteristics of those who receive reports, wrongdoers' characteristics, and organizations' characteristics.

One of whistleblowers' characteristics that likely affects individuals' intention to commit whistleblowing is the retaliation consideration (Kaplan, Pany, Samuels, \& Zhang, 2012). An experiment study of Liyanarachchi and Newdick (2009) tests the effects of retaliation power and moral level of New Zealand accounting students on their tendency to commit whistleblowing when they are confronted with a serious problem. The results show that participants tend to commit whistleblowing when retaliation is 
weak, but not when it is strong. Bjorkelo, Einarsen, Nielsen, and Matthiesen (2011) explain that whistleblowers exhibit less work satisfaction and are subject to more bullying behavior in their workplace than non-whistleblowers. Thus, retaliation discourages members of organizations to commit whistleblowing (Kaplan, Pany, Samuels, \& Zhang, 2012).

Another factor that affects whistleblowing is seriousness of wrongdoing (Curtis, 2006). Robinson, Robertson, \& Curtis (2012); Brink, Cereola, \& Menk (2015) examine and classify seriousness of wrongdoing into two parts, namely material and immaterial wrongdoings. Their findings demonstrate that individuals exhibit greater whistleblowing intention when seriousness of wrongdoing is material than when it is immaterial.

Previous studies (Kaplan, Pany, Samuels, \& Zhang, 2012), (Curtis, 2006), (Robinson, Robertson, \& Curtis, 2012) that investigate the effects of retaliation and seriousness of wrongdoing on whistleblowing intention tend to focus on auditors or accountants in the private sector. However, in the government sector, municipal or provincial inspectorate (government internal auditors) as a part of internal control also plays a crucial role in whistleblowing. In Indonesia, Government Regulation No. 60 Year 2008 on the Government Internal Control System especially article 11 mentions that inspectorates have a role in providing an early warning, in enhancing the effectiveness of risk management and in improving the governance quality. Thus, studies on whistleblowing in the public sector are still potential to extend.

This study extends Liyanarachchi \& Newdick (2009) who have not taken the seriousness of wrongdoing factor in their analysis into the government inspectorate environment. Specifically, this research aims to test the causal relationships between seriousness of wrongdoing and retaliation on whistleblowing intention. It is expected that this study contributes to the whistleblowing literature and future studies. Additionally, this research also contributes to the government by helping develop fraud disclosure systems.

\section{Literature Review}

\subsection{Theory of Planned Behaviour (TPB)}

Theory of Planned Behaviour (TPB) is an extension of the Theory of Reasoned Action (TRA). In general, the Theory of Planned Behavior explains that intention is shaped and affected by certain factors. Next, intention motivates individual behavior (Ajzen, 1991). Theory of Reasoned Action suggests that two key factors affect individual intention, namely subjective norms and attitude toward behavior. Theory of Planned Behavior adds this argument by proposing three key factors that affect intention, namely, attitude toward behavior, subjective norms, and perceived behavioral control (Park \& Blenkinsopp, 2009).

Attitude refers to individual assessment on whether a certain behavior is accepted or rejected (Alleyne, Hudaib, \& Pike, 2013). Meanwhile, subjective norms are closely related to social pressures that likely affect individual perception. Lastly, perceived behavioral control is the perception of the strength of factors that facilitate or inhibit a certain behavior (Ajzen, 1991).

\subsection{Retaliation}

Retaliation is an unwanted action toward whistleblowers as a direct response of their decisions to report frauds internally or externally (Rehg, Near, Miceli, \& Scotter, 2008). Retaliation can take various forms, such as demotion, authority reduction or even removal, excessive assignment, and even job dismissal (Mesmer-Magnus \& Viswesvaran, 2005). Einarsen (2000) reveals that retaliation toward whistleblowers is similar to bullying behavior at the workplace. Bullying itself refers to a situation where individuals are subject to continuous psychological torture.

Leymann (1996) explains in detail that bullying behavior harms individuals by affecting their opportunities to communicate (e.g., a threat to cut information), their ability to maintain social contacts (e.g., physical exclusion or social mutation), their ability to protect their personal reputation (e.g., defamation), and even their health (e.g., assignment to dangerous jobs, sexual harassment, and physical attacks). Further, being in such a position continuously may cause individuals to have stress, trauma, and even mental health problems (Tehrani, 2004). Besides health problems, retaliation may also harm whistleblowers' financial aspects and relationship with their families and relatives. 


\subsection{Seriousness of Wrongdoing}

Seriousness of wrongdoing refers to the characteristic of wrongdoing. The seriousness of wrongdoing concept is closely related to the materiality concept in accounting. Schultz, Johnson, \& Dyrnes (1993) explain that because of its relationship with the materiality concent in accounting, seriousness of wrongdoing can be quantitatively measured. However, Curtis (2006) extensively proposes that seriousness of wrongdoing is not limited to quantitative concepts, but also qualitative ones. For example, studies can identify the extent of the negative effects of wrongdoing and the likelihood that the wrongdoing harms others.

Concerning fraud detection, materiality is worth considering. Even Wells (2003) argues that "the presence of immaterial fraud may be the 'tip of the iceberg' for exposing more pervasive frauds."

\subsection{Whistleblowing Intention}

Whistleblowing is defined as a reporting action made by members of organizations on illegal or immoral actions within their organizations to external or internal parties that potentially affects the wrongdoings (Near \& Miceli, 1985). Whistleblowing can also be defined as an action committed by responsible organizational spies who dare to act based on following their conscience (Mustapha \& Siaw, 2012). Ones can commit whistleblowing both directly or indirectly through anonymous reporting mechanisms (Taylor \& Curtis, 2013).

Whistleblowing is a reliable monitoring system to detect existing fraud (Alleyne, Hudaib, \& Pike, 2013). Individuals who are aware of fraud and intent to report the fraud will give positive impacts on their organizations (Near \& Miceli, 2016). In an analysis of 128 US students, Elias (2008) demonstrates that students consider whistleblowing necessary, especially in a fraud case. Employees often understand the importance of whistleblowing. However, potential whistleblowers are confronted with an ethical dilemma between reporting fraud they are aware of and keeping fraud undisclosed (Suyatno, Armstrong, \& Thomas, 2017).

\subsection{The Relationship between Retaliation and Whistleblowing Intention}

Changes in cultural values have enabled individuals to judge and defend what they consider right. However, committing whistleblowing invites various consequences and even retaliation (Rocha \& Kleiner, 2005). Elias (2008) explain that higher risks such as retaliation and potential difficulties in having future jobs in the same profession discourage individuals to commit whistleblowing. In this respect, individuals base their decisions to report frauds on the costs and benefits of these decisions (Gundlach, Douglas, \& Martinko, 2003) that will change due to various factors, including the history of previous whistleblowers.

Kaplan, Pany, Samuels, \& Zhang (2012) hold that the history of previous whistleblowers is a signal for potential whistleblowers to assess whether they will experience retaliation. Retaliation is a potential cost. A higher potential cost will arguably reduce one's intention to commit whistleblowing. In other words, individuals are more likely to conceal fraud when potential risks are greater (Nickolan, Handajani, \& Hermanto, 2018). The retaliation consideration is not only related to its likelihood but also the magnitude of the retaliation (Liyanarachchi \& Adler, 2011).

Whistleblowers in the government sector also face potential retaliation. In turn, retaliation motivates the government to develop further the mechanism to protect whistleblowers from retaliation. For example, as an example, Minister of Research, Technology, and Education Regulation No. 3 Year 2014 article 6 on Guidelines on Management and Follow-Up of Whistleblowing in Each Institution's Environment stipulates that whistleblowing system is compulsory to protect whistleblowers from retaliation and those who retaliate must be punished. Thus, the following is our first hypothesis:

H1: Subjects who receive low retaliation condition will exhibit greater whistleblowing intention than subjects who receive high retaliation condition.

\subsection{The Relationship between Seriousness of Wrongdoing and Whistleblowing Intention}

Perceive behavioral control in TPB refers to the perceived ease or difficulty of committing a behavior. In turn, intention and behavior depend on individuals' resources and opportunities to commit a certain behavior. Each inherent obstacle or risk is labeled as a control factor. Next, individuals' beliefs on 
the opportunity or obstacle are built upon and affected by various factors, including others' information and experience (Ajzen, 1991). Perceived behavioral control is the basis of actual behaviors. Thus, individuals are the judges for their behaviors.

An important control factor in whistleblowing comes from the trust of organizational obstacles that are related to the neglect of reports given. Individuals who believe that their reports will not be responded well will consider their reports will not improve their organizations (Park \& Blenkinsopp, 2009). Another obstacle is a concern about potential retaliation due to their reports. Thus, it is important for individuals to understand how they will be responded to and receive legal protection.

Several previous studies demonstrate the effect of seriousness of wrongdoing on individuals'

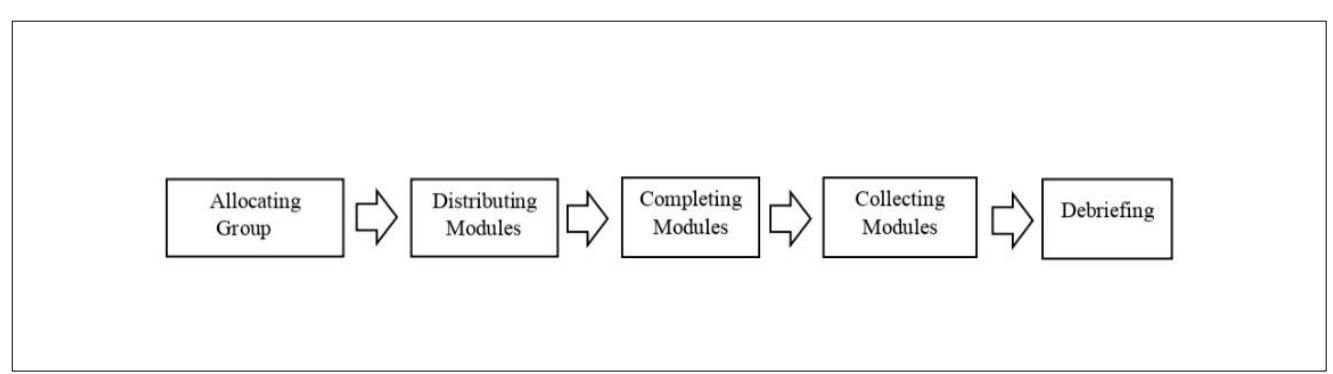

whistleblowing intention. These papers also explain that individuals exhibit greater whistleblowing intention when wrongdoings are material (Curtis, 2006); (Robinson, Robertson, \& Curtis, 2012); (Brink, Cereola, \& Menk, 2015). The findings can be explained by the fact that more serious fraud involves more money and has more impacts on organizations (Curtis, 2006). Then, individuals tend to perceive that organizations are more likely to corrective actions for more serious problems.

Organizations will experience greater or more material losses from more serious mistakes. Individuals, especially as parts of organizations, perceive that they have responsibilities to protect their workplaces from losses and other negative impacts (Winardi, 2013). Thus, the study proposes the second hypothesis as follows:

$\mathrm{H} 2$ : Subjects who receive high seriousness of wrongdoing condition will exhibit greater whistleblowing intention than subjects who receive low seriousness of wrongdoing condition.

\section{Method}

\subsection{Research Design}

This study is experimental research with a $2 \times 2$ inter-subjects factorial design. The main benefit of experimental research is that it explains the causal relationship between the observed dependent and independent variables (Utami \& Nahartyo, 2013). The subjects are government internal auditors. The dependent variable is whistleblowing intention, while the independent variables are retaliation and seriousness of wrongdoing.

The experiment operationalized retaliation into two levels, namely high and low retaliation. Meanwhile, the study operationalized the seriousness of wrongdoing variable into two levels: material condition and immaterial condition. The following Table 1 displays the matrix of the experiment design.

Table 1. Experiment Matrix

\begin{tabular}{lllc}
\hline & & \multicolumn{2}{c}{ Seriousness of wrongdoing } \\
\cline { 2 - 4 } & & Material & Immaterial \\
\hline \multirow{2}{*}{ Retaliation } & High & Group 1 & Group 2 \\
\cline { 2 - 4 } & Low & Group 3 & Group 4 \\
\hline
\end{tabular}

\subsection{Experiment Setting}

The experiment consisted of five phases that are illustrated in Figure 1. The first phase divided subjects randomly into each group, as indicated by the experiment matrix. Each group received a manipulation treatment according to each condition.

Figure 1. Experiment Flow 
Subjects then received assignment modules. The module informed that subjects acted as a member of Inspectorate (government auditors) who was assigned to audit a regional education office of a city/regency as a part of a routine audit (Annual Monitoring Work Program). Then, the scenario explained that subjects found that the upper echelon of the regional education office illegally cooperated with the vendor of school textbooks with a kickback mechanism. The illegal act caused financial loss to the government. Subjects were required to assess the extent of their whistleblowing intention through the Whistleblowing System (WBS) that had been developed by the Inspectorate where they worked through the website anonymously to ensure that their identity is protected.

Subjects who received the manipulation of material seriousness of wrongdoing were conditioned that the amount of government loss was 1 billion Rupiah that was identified material. Meanwhile, for the immaterial seriousness of wrongdoing, subjects were conditioned that the amount of government loss was 10 million Rupiah, and it was immaterial. Next, subjects who received the high retaliation condition were informed that if subjects reported the fraud, it was likely that they received retaliation in the form of job dismissal and even threats to their family members. In the low retaliation condition, it was much less likely that subjects would receive retaliation.

The study ran the manipulation check by using the information test. The information test was presented in three questions for each manipulation. After each phase was completed, the debriefing session closed the experiment. The debriefing session aimed to restore subjects to their previous condition. In this session, subjects were informed that their involvement in this experiment was voluntary, and they could withdraw the results if they had the objection with the study. This debriefing session was a manifestation of researchers' ethical responsibility.

\subsection{Analytical Techniques}

The first phase in the analysis presented subjects' profiles by using descriptive statistics. The study then tested the effectiveness of randomization by using One-Way Analysis of Variance (ANOVA) test to ensure that subjects' whistleblowing intention was not affected by their demographic factors. The randomization was effective if the significance value was greater than $\alpha=5 \%$. Next, an Independent Sample T-test analyzed whether the hypotheses were empirically supported. Hypotheses would be empirically supported (rejected) if the significance value was less (greater than) $\alpha=5 \%$.

\section{Result and Discussion}

\subsection{The General Description of the Experiment Subjects}

Research data was collected through a laboratory experiment on government internal auditors in Kupang, East Nusa Tenggara. Forty-five subjects were allocated randomly to four groups with different conditions according to the research scenario. A participant did not fill in the questionnaire completely, leaving 44 participants who qualified into the subsequent phase. Table 2 below shows the profiles of all qualifying participants.

Table 2. Participants' Profiles

\begin{tabular}{lcc}
\hline \multicolumn{1}{c}{ Explanation } & Total & Percentage \\
\hline Sex: & 30 & $68 \%$ \\
$\quad$ Male & 14 & $32 \%$ \\
Female & & \\
Age: & 6 & $14 \%$ \\
28-34 years & 12 & $27 \%$ \\
35-41 years & 19 & $43 \%$ \\
42-48 years & 6 & $14 \%$ \\
49-55 years &
\end{tabular}




\section{Working Experience:}

$\begin{array}{lcc}\leq 3 \text { years } & 1 & 2 \% \\ >3-5 \text { years } & 8 & 18 \% \\ >5 \text { years } & 35 & 80 \%\end{array}$

\section{Source: Processed Primary Data}

The results demonstrate that most of the participants were male $(30$ subjects or $68 \%$ of total participants) while the rest were female (14 subjects or $32 \%$ of total participants). Next, participants with the age range of $42-48$ years dominated with 19 subjects $(43 \%)$ and only one subject $(2 \%)$ was above 55 years. Lastly, most participants (35 or $80 \%$ ) had worked for more than five years.

\subsection{Randomization Check}

The study ran the randomization check before the hypothesis testing. Randomization check was performed with One-Way Analysis of Variance (One-Way ANOVA) on participants' demographic factors, namely sex, age, and years of working experience. This test aimed to analyze whether demographic factors affect the dependent variable. Table 3 displays the results of the randomization check.

Table 3. The Results of One-Way ANOVA

\begin{tabular}{|c|c|c|c|c|}
\hline & Mean Square & $\mathbf{F}$ & Sig. & Explanation \\
\hline \multicolumn{5}{|l|}{ Sex: } \\
\hline $\begin{array}{l}\text { Between } \\
\text { Groups }\end{array}$ & 75.346 & 0.165 & 0.687 & No Effect \\
\hline Within Groups & 457.676 & & & \\
\hline \multicolumn{5}{|l|}{ Age: } \\
\hline $\begin{array}{l}\text { Between } \\
\text { Groups } \\
\text { Within Groups }\end{array}$ & $\begin{array}{l}738.906 \\
419.028\end{array}$ & 1.763 & 0.156 & No Effect \\
\hline $\begin{array}{l}\text { Working Experien } \\
\text { Between } \\
\text { Groups } \\
\text { Within Groups }\end{array}$ & $\begin{array}{r}10.828 \\
470.148\end{array}$ & 0.23 & 0.977 & No Effect \\
\hline
\end{tabular}

The results show that all three demographic factors had significance values greater than alpha (0.05), indicating that these demographic factors did not affect subjects' whistleblowing intention. Thus, the test suggested that the randomization was effective by allowing only the manipulation treatment that affected subjects' whistleblowing intention.

\subsection{Test of Hypothesis 1}

The first hypothesis predicts that subjects who face low retaliation condition will exhibit greater whistleblowing intention than those who face high retaliation condition. The study tested the first hypothesis by using the independent sample t-test to compare the whistleblowing intention of the two groups with different treatments (group 1 and group 2 with the high retaliation condition and group 3 and 4 with the low retaliation condition). Table 4 displays the results of the test of hypothesis one.

Table 4. The Results of the Test of Hypothesis One 


\begin{tabular}{lllccc}
\hline & N & Mean & $\begin{array}{c}\text { Std. } \\
\text { Deviation }\end{array}$ & t & $\begin{array}{c}\text { Sig. } \\
\text { (2-tailed) }\end{array}$ \\
\hline Retaliation & & & & & \\
$\quad$ High Retaliation & 23 & 68.70 & 22.422 & -4.308 & 0.000 \\
$\quad$ Low Retaliation & 21 & 91.90 & 10.779 & -4.434 & \\
\hline
\end{tabular}

The results in Table 4 produced a significance value of $0.000<0.05$ (equality of means assumed), implying that there was a significant difference between these two groups. Subjects who received high (low) retaliation had a mean value of 68.70 (91.90). The results suggest that subjects who receive low retaliation condition tended to exhibit greater whistleblowing intention (as indicated by the mean score approaching 100) than subjects who received high retaliation condition.

The results are in line with previous studies (Liyanarachchi \& Newdick, 2009; Fatoki, 2013) that argue that high retaliation reduces individuals' whistleblowing intention. Auditors take retaliation as a cost into consideration. A greater cost or risk motivates auditors to reject to commit whistleblowing and to cover information they have (Nickolan, Handajani, \& Hermanto, 2018).

\subsection{Test of Hypothesis 2}

The second hypothesis predicts that subjects who receive high seriousness of wrongdoing (material) condition exhibit greater whistleblowing intention than subjects with low seriousness of wrongdoing condition. Similar to the test of hypothesis one, the study tested hypothesis two by using the independent sample t-test to compare two groups with different treatments. The first group (group 1 and group 3) received high seriousness of wrongdoing condition while the second group (group 2 and 4) received low seriousness of wrongdoing condition. Table 5 shows the results of the hypothesis testing.

Table 5. The Results of the Test of Hypothesis Two

\begin{tabular}{lccccc}
\hline & N & Mean & Std. Deviation & t & $\begin{array}{c}\text { Sig. (2- } \\
\text { tailed) }\end{array}$ \\
\hline $\begin{array}{l}\text { Seriousness of Wrongdoing } \\
\quad \text { Material }\end{array}$ & 22 & 83.64 & 17.056 & 3.213 & \\
$\quad$ Immaterial & 22 & 58.64 & 32.263 & 3.213 & 0.003 \\
\cline { 1 - 2 }
\end{tabular}

Table 5 displays a 2-tailed significance value of $0.03<0.05$, implying that there was a significant difference between the two tested groups. Next, the mean value of subjects with high (low) seriousness of wrongdoing condition is 83.64 (58.64). The results suggest that subjects with high seriousness of wrongdoing condition were likely to exhibit greater whistleblowing condition (a mean score approaching 100) than subjects with low seriousness of wrongdoing condition.

The results are in line with (Brink, Cereola, \& Menk, 2015); (Robinson, Robertson, \& Curtis, 2012) who demonstrate that individuals exhibit greater whistleblowing intention when wrongdoings are material. Individuals tend to perceive that material wrongdoings increase the likelihood that their reports will be responded better. Conversely, immaterial wrongdoings lead to poor responses to reports. Individuals believe that the absence of good responses will fail to fix the problems (Park \& Blenkinsopp, 2009).

Poor responses can be considered as a control factor that affects auditors' perception or perceived behavioral control as explained by the Theory of Planned Behaviour. Internal auditors' intention to commit whistleblowing depends on available resources and obstacles. Poor responses are considered an obstacle, and greater obstacles imply auditors' less intention to commit whistleblowing.

\section{Conclusion, Implication, and Suggestion}

This study aims to test the causal relationships between retaliation and seriousness of wrongdoing and government internal auditors. The findings demonstrate that retaliation and seriousness of wrongdoing affected whistleblowing intention. The whistleblowing intention of internal auditors as the research subjects was greater when they had low retaliation condition. Next, auditors were likely to 
exhibit greater whistleblowing intention when they had high seriousness of wrongdoing condition than when they had immaterial wrongdoing.

The study contributes to the whistleblowing literature and future studies. Also, the results advise organizations, especially public sector ones, to develop effective whistleblowing systems to facilitate disclosure better and to provide better protection for whistleblowers. 


\section{References}

[1]ACFE.: Report To The Nations. USA: ACFE. Retrieved from https://s3-us-west2.amazonaws.com/acfepublic/2018-report-to-the-nations.pdf. pp. 1-80 (2018).

[2]Ajzen, I.: The Theory of Planned Behavior. Organizational Behavior and Human Decision Processes. pp. 179-211 (1991).

[3]Alleyne, P., Hudaib, M., \& Pike, R.: Towards a conceptual model of whistle-blowing intentions among external auditors. The British Accounting Review. pp. 10-23 (2013).

[4]Bjorkelo, B., Einarsen, S., Nielsen, M. B., \& Matthiesen, S. B.: Silence is golden? Characteristics and experiences of self-reported whitleblowers. European Journal of Work and Psychology. pp. 206-238 (2011).

[5]Brink, A. G., Cereola, S. J., \& Menk, K. B.: The Effects of Personality Traits, Ethical Position, and the Materiality of Fraudulent Reporting on Entry-level Employee Whistleblowing Decisions. Journal of Forensic \& Investigative Accounting. pp. 180-211 (2015).

[6]Curtis, M. B.: Are Audit-Related Ethical Decisions Dependent Upon Mood? Journal of Business Ethics. pp. 191-209 (2006).

[7]Dimant, E., \& Tosato, G.: Causes and effects of corruption: What has past decade's empirical research taught us? A Survey. Journal of Economics Survey. pp. 335-356 (2017).

[8]Dyck, A., Morse, A., \& Zingales, L.: Who Blows the Whistle on Corporate Fraud? The Journal of Finance. pp. 2213-2253 (2010).

[9]Einarsen, S.: Harassment and bullying at work: A review of the Scandinavian approach. Aggression and Violent Behavior. pp. 379-401 (2000).

[10]Elias, R.: Auditing students' professional commitment and anticipatory socialization and their relationship to whistleblowing. Managerial Auditing Journal. pp. 283-294 (2008).

[11]Fatoki, O.: Internal Whistleblowing Intentions of Accounting Students in South Africa: The Impact of Fear of Retaliation, Materiality, and Gender. Journal of Social Sciences. pp. 31-44 (2013).

[12]Gao, L., \& Brink, A. G.: Whistleblowing studies in accounting research: A review of experimental studies on the determiants of whistleblowing. Journal of Accounting Literature. pp. 1-13 (2017).

[13]Gundlach, M. J., Douglas, S. C., \& Martinko, M. J.: The Decision to Blow the Whistle: A Social Information Processing Framework. The Academy of Management Review. pp. 107-123 (2003).

[14]Kaplan, S., Pany, K., Samuels, J., \& Zhang, J.: An examination of anonymous and non-anonymous fraud reporting channels. Advances in Accounting. pp. 88-95 (2012).

[15]Kayes, D. C., Stirling, D., \& Nielsen, T. M.: Building organizational integrity. Business Horizons. pp. 61-70 (2007).

[16]Leymann, H.: The content and development of mobbing at work. European Journal of Work and Organizational Psychology. pp. 165-184 (1996).

[17]Liyanarachchi, G. A., \& Adler, R.: Accountants' Whistle-Blowing Intentions: The Impact of Retaliation, Age, and Gender. Australian Accounting Review. pp. 167-182 (2011).

[18]Liyanarachchi, G., \& Newdick, C. The Impact of Moral Reasoning. Journal of Business Ethics. pp. 37-57 (2009).

[19]Mesmer-Magnus, J. R., \& Viswesvaran, C.: Whistleblowing in Organizations: An Examination of Correlates of Whistleblowing Intentions, Actions, and Retaliation. Journal of Business Ethics. pp. 277297 (2005).

[20]Miceli, M. P., \& Near, J. P.: Whistleblowing: Reaping the Benefits. Academy of Management. pp. 65-72 (1994).

[21]Mustapha, M., \& Siaw, L. S.: Whistle Blowing: Perceptions of Future Accountants. International Conference on Economics Business Innovation. pp. 135-139 (2012).

[22]Near, J. P., \& Miceli, M. P: Organizational Dissidence: The Case of Whistle-Blowing. Journal of Business Ethics. pp. 1-16 (1985).

[23]Near, J. P., \& Miceli, M. P.: After the wrongdoing: What managers should know about whistleblowing. Business Horizons. pp. 105-114 (2016).

[24]Near, J. P., \& Miceli, M. P.: Wrongdoing, Whistle-Blowing, and Retaliation in the U.S. Government: What Have Researchers Learned From the Merit Systems Protection Board (MSPB) Survey Results? Review of Public Personnel Administration. pp. 263-281 (2008). 
[25]Near, J. P., Rehg, M., Scotter, J. R., \& Miceli, M. P.: Does type of wrongdoing affect the whistleblowing process? Business Ethics Quarterly. pp. 219-242 (2004).

[26]Nickolan, F., Handajani, L., \& Hermanto.: Whistleblowing Intention of Indonesian Government Internal Auditor (APIP) and Anonymous Reporting Channel Interactions. International Journal of Economics, Commerce, and Management. pp. 161-175 (2018).

[27]Park, H., \& Blenkinsopp, J.: Whistleblowing as Planned Behavior-A Survey of South Korean Police Officers. Journal of Business Ethics. pp. 545-556 (2009).

[28]Pratiwi, P. S.: Suap Auditor BPK Hasil Patungan Pejabat Eselon I Kemendes. Retrieved 22 Januari 2019, from https://www.cnnindonesia.com/nasional/20170816125202-12-235124/suap-auditor-bpk-hasilpatungan-pejabat-eselon-i-kemendes (2017).

[29]Rehg, M. T., Near, J. P., Miceli, M. P., \& Scotter, J. R.: Antecedents and Outcomes of Retaliation Against Whistleblowers: Gender Differences and Power Relationships. Organization Science. pp. 221240 (2008).

[30]Reilly, P.: Was Machiavelli Right? Lying in Negotiation and the Art of Defensive Self-Help. Ohio State Journal on Dispute Resolution. pp. 481 (2009).

[31]Robinson, S. N., Robertson, J. C., \& Curtis, M. B.: The Effects of Contextual and Wrongdoing Attributes on Organizational Employees' Whistleblowing Intentions Following Fraud. Journal of Business Ethics. pp. 213-227 (2012).

[32]Rocha, E., \& Kleiner, B. H.: To blow or not to blow the whistle? That is the question. Management Research News. pp. 80-87 (2005).

[33]Schultz, J. J., Johnson, D. A., \& Dyrnes, S.: An Investigation of the Reporting of Questionable Acts in an International Setting. Journal of Accounting Research. pp. 75-103 (1993).

[34]Seifert, D. L., Sweeney, J. T., Joireman, J., \& Thornton, J. M.: The influence of organizational justice on accountant whistleblowing. Accounting, Organizations, and Society. pp. 707-717 (2010).

[35]Suyatno, B., Armstrong, A., \& Thomas, K.: Barriers to Whistleblowing Intentions and Reporting Channel Preferences. 19th International Scientific Conference on Economic and Social Development. Melbourne: Victoria University. pp. 115-128 (2017).

[36]Tallo, J.: Ketua KPK: Pelapor Dugaan Korupsi Dapat Hadiah dari Negara. Retrieved 23 Januari 2019 from https://www.liputan6.com/news/read/3660564/ketua-kpk-pelapor-dugaan-korupsi-dapat-hadiahdari-negara (2018).

[37]Taras, V., Kirkman, B., \& Steel, P.: Examining the Impact of Culture's Consequences: A ThreeDecade, Multilevel, Meta-Analytic Review of Hofstede's Cultural Value Dimensions. Journal of Applied Psychology. pp. 405-439 (2010).

[38]Taylor, E. Z., \& Curtis, M. B.: Whistleblowing in Audit Firms: Organizational Response and Power Distance. Behavioral Research in Accounting. pp. 21-43 (2013).

[39]Tehrani, N.: Bullying: A Source of Chronic Post Traumatic Stress? British Journal of Guidance and Counselling. pp. 358-366 (2004).

[40]Utami, I., \& Nahartyo, E.: Riset eksperimen pengauditan: Evolusi dan topik kontemporer. Jurnal Akuntansi dan Keuangan Indonesia. pp. 60-79 (2013).

[41]Wells, J. T.: The padding that hurts. Journal of Accountancy. pp. 67-69 (2003).

[42]Winardi, R. D.: The Influence of Individual and Situational Factors on Lower-Level Civil Servants' Whistle-Blowing Intention in Indonesia. Journal of Indonesian Economy and Business. pp. 361-376 (2013). 